\title{
Effects of diabetic cardiomyopathy on regional electrophysiologic characteristics of rat ventricle
}

\author{
O.Casis ${ }^{1}$, M. Gallego ${ }^{1}$, M. Iriarte ${ }^{2}$, J.A.Sánchez-Chapula ${ }^{3}$ \\ ${ }^{1}$ University of the Basque Country, School of Pharmacy, Department of Physiology, Bilbao, Spain \\ ${ }^{2}$ Foundation for Research and Teaching of Cardiovascular Diseases (FIDEC), Bilbao, Spain \\ ${ }^{3}$ University Centre for Biomedical Research, University of Colima, Mexico
}

\section{Abstract}

Aims/hypothesis. To identify the possible causes of the lengthening of the action potential duration described in patients affected by diabetes mellitus.

Methods. We studied the effects of streptozotocininduced diabetes on the current density of the repolarising potassium currents $\mathrm{I}_{\mathrm{to}}, \mathrm{I}_{\mathrm{K}}, \mathrm{I}_{\mathrm{ss}}$ and $\mathrm{I}_{\mathrm{K} 1}$ in enzymatically isolated myocytes from three different regions of rat heart: total right ventricle, subepicardium at the apex of the left ventricle and subendocardium at the base of the left ventricle.

Results. No changes in $\mathrm{I}_{\mathrm{K} 1}$ were found due to diabetes, but there was a uniform decrease in $\mathrm{I}_{\mathrm{to}}(50 \%)$ and $I_{\mathrm{ss}}(40 \%)$ current densities in the three regions.
In contrast, $\mathrm{I}_{\mathrm{K}}$ diminished unevenly, with the greatest decrease in the subendocardium at the base of the left ventricle $(48 \%)$, followed by the subepicardium at the apex of the left ventricle $(32 \%)$ and right ventricle $(10 \%)$.

Conclusion/interpretation. These findings suggest the existence of regional differences in ion channel expression associated with diabetes. The decrease of these repolarising currents could account for the lengthening of action potential and the consequent change in the Q-T interval of the ECG observed in diabetic rats. [Diabetologia (2000) 43: 101-109]

Keywords Patch-clamp, potassium currents, diabetes, action potential, rat.
The electrocardiogram of diabetic patients shows a series of deviations from normal patterns, most of which involve the QT interval and the $\mathrm{T}$ wave. The QT interval is longer in patients with diabetes mellitus than in normal people [1]. Diabetic patients show a corrected QT interval (QTc), measured using Bazett's formula, longer than $0.44 \mathrm{~s}[2,3]$. Using Holter ECG monitoring, the appearance of ventricular late potentials is more frequent in patients with Type I

Received: 30 March 1999 and in revised form: 23 June 1999

Corresponding author: Dr. O. Casis, University of the Basque Country, School of Pharmacy, Department of Physiology, PO Box 699, 48080 Bilbao, Spain

Abbreviations: EpiALV, Subepicardium at the apex of the left ventricle; EndoBLV, subendocardium at the base of the left ventricle; RV, right ventricle; RP, resting potential; APA, Action potential amplitude; APD, action potential duration; TEA, Tetraethylammonium; HP, holding potential; KB, Kraftbrühe. (insulin-dependent) diabetes mellitus than in healthy people, and even more frequent in patients with Type II (non-insulin-dependent) diabetes mellitus [4, 5]. Nearly all these changes are related to repolarisation. The QRS complex lasts longer in diabetic patients than in control subjects, suggesting intracardiac conduction disorders, but this type of change has only been described in children [6].

Various studies report a lengthening of the duration of the rat ventricular action potential (APD) stemming from diabetic cardiomyopathy as a possible cause of these changes [7-9]. None took into account, however, the regional variability in the duration of the action potential under control conditions [10, 11]. Various reports pointed to a lowering of the transient outward current, $\mathrm{I}_{\text {to }}[9,12,13]$ and, to a lesser extent, the delayed rectifying outward current, $\mathrm{I}_{\mathrm{K}}[9$, 12], as the main cause of the lengthening of APD. Initial studies did not take into account regional variations in the distribution of the repolarising outward 
potassium currents $[9,12,13]$. A more recent study only used animals with diabetes of short duration, 6 to 7 days after streptozotocin treatment [14]. In addition, in this study [14] the depolarisation-activated outward potassium current was supposed to be composed of $\mathrm{I}_{\text {to }}$ and $\mathrm{I}_{\mathrm{K}}[15]$. A novel repolarising current, $\mathrm{I}_{\mathrm{ss}}$, has recently been described in rat ventricular myocytes [16]. This current shows no time-dependent inactivation, a weak voltage-dependent inactivation and is highly inhibited by isoprenaline. This non-inactivating current could play an important part in the modulation of action potential duration during adrenergic stimulation.

Therefore, we have studied the regional alterations that occur in the transient outward, $\mathrm{I}_{\mathrm{to}}$, delayed rectifier, $\mathrm{I}_{\mathrm{K}}$, steady-state, $\mathrm{I}_{\mathrm{ss}}$, and inward rectifier, $\mathrm{I}_{\mathrm{K} 1}$, repolarising ionic currents 4 weeks after Type I diabetes was induced by streptozotocin. The effect of diabetes induced by streptozotozin on action potential waveform reaches its maximum by 4 weeks [13]. In the lifespan of a rat this can be considered as longterm diabetes.

\section{Materials and methods}

Induction of diabetes. Young adult Wistar rats were separated into two groups. The control group was 10-12 weeks old and 200-250 g in weight. The experimental group was 6-8 weeks old at induction of Type I diabetes. Experiments were carried out 4 weeks after induction, so the animals were 10-12 weeks old when the myocytes were isolated. Diabetic rats weighed 180-220 g, because of the weight loss induced by diabetes. These data agree with those published previously [17].

After anaesthetising the animals with an intraperitoneal injection of sodium pentobarbital $(40 \mathrm{mg} / \mathrm{kg})$, the femoral vein was dissected to enable a slow injection of $65 \mathrm{mg} / \mathrm{kg}$ body weight of streptozotocin. After topical application of sulphathiazole to avoid possible infection, the wound was closed with 2-3 sutures. The animals in the control group were subjected to the same treatment, using a citrate buffer vehicle, without streptozotocin. As early as 2 days after injection, the first symptoms of Type I diabetes, polyuria and polydypsia, became evident and were shortly followed by appreciable polyphagia and weight loss. Electrophysiological experiments were done 30 days after injection when Type I diabetes was well stabilised and streptozotocin was totally cleared from the body. Blood samples were taken during the surgical procedure and immediately before the experiment. Glucose concentrations were $7.5 \pm 1.1 \mathrm{mmol} / \mathrm{l}$ in healthy animals compared $23.5 \pm 1.1 \mathrm{mmol} / 1$ in diabetic animals $(p<0.01)$. None of the animal groups received insulin treatment.

Cell isolation. After anaesthesia with an intraperitoneal injection of sodium pentobarbital $(35 \mathrm{mg} / \mathrm{kg})$, animals were killed by cervical dislocation. The thoracic cavity was opened and the heart quickly excised and suspended by the aorta in a Langendorff perfusion apparatus.

The isolated heart was perfused with a Tyrode solution. Next, the heart was perfused for $7 \mathrm{~min}$ with the same Tyrode solution without $\mathrm{Ca}^{+2}$ and for 15 min with a nominally $\mathrm{Ca}^{+2}$ free solution supplemented with type I collagenase $(0.5 \mathrm{mg} /$ $\mathrm{ml})$ and type XIV protease $(0.03 \mathrm{mg} / \mathrm{ml}$; Sigma Chem. Co., St.
Louis, Mo.). Finally, to remove enzymes, the hearts were perfused for 5 min with a Kraftbrühe (KB) solution [18]. Hearts were removed from the apparatus and the different regions to be studied were sectioned with microsurgical scissors. We isolated myocytes from the whole wall of the right ventricle $(\mathrm{RV})$ and from two different regions of the left ventricle, the subepicardium at the apex (EpiALV) and the subendocardium at the base (EndoBLV). These ventricular regions show differences in action potential duration [11]. Myocytes were dispersed by mechanical agitation. Cell suspensions were kept at $5^{\circ} \mathrm{C}$ in the $\mathrm{KB}$ solution for at least $2 \mathrm{~h}$ before use in experiments.

Aliquots of the myocyte suspension were transferred to a shallow chamber ( $3 \mathrm{ml}$ volume) mounted on the stage of an inverted microscope, where the cells were allowed to settle for $10 \mathrm{~min}$ before being superfused with normal Tyrode solution. For our experiments, we only used $\mathrm{Ca}^{+2}$-tolerant rod-shaped cells, with clear cross striations and lacking any visible blebs on their surfaces. All experiments were done at room temperature $\left(21-23^{\circ} \mathrm{C}\right)$.

Principles of animal care (NIH publication no. 85-23, revised 1985) were followed.

Recording techniques. Recording of $\mathrm{K}^{+}$currents and action potential waveforms was done using the whole-cell variation of the patch-clamp technique [19]. Both current-clamp and voltage-clamp recordings were done with an Axopatch 200A patch-clamp amplifier, connected to a Digidata 1200 A/D converter (Axon Instruments, Foster City, Calif., USA). Sampling and filtering frequencies were $4 \mathrm{KHz}$ and $1 \mathrm{KHz}$, respectively. After formation of a gigaseal between the pipette and cell membrane, pipette capacitance was fully compensated electronically. After patch rupture, whole-cell membrane capacitances were measured by integration of capacitive transients that were elicited by voltage steps from -50 to $-60 \mathrm{mV}$, averaging $84.1 \pm 5.9 \mathrm{pF}$. There was no statistically significant difference between control and diabetic cells. Small cells were selected when possible to improve the voltage-clamp. All current-clamp and voltage-clamp experimental protocols were controlled using the Clampex program of pClamp 5.1 software (Axon Instruments).

Pipettes were made from borosilicate tubes. To reduce voltage errors, series resistance was minimised by selecting low resistance electrodes (1-3 M $\Omega$ ) and by using electronic compensation $(80 \%)$.

Action potentials were recorded immediately after patch rupture, to avoid the run-down of the $\mathrm{Ca}^{+2}$ current. The $\mathrm{K}^{+}$currents were recorded 8-10 min after perfusion with $\mathrm{Co}^{+2}$ containing solution. None of the $\mathrm{K}^{+}$currents studied showed runup or run-down.

Measurement of $\mathrm{K}^{+}$currents. In rat ventricular myocytes three different outward $\mathrm{K}^{+}$currents activated by depolarisation have been described. A rapidly activating and inactivating $I_{\text {to }}$, sensitive to 4-aminopyridine (4-AP), a rapidly activating, slowly inactivating $\mathrm{I}_{\mathrm{K}}$, sensitive to external tetraethylammonium (TEA) [15], and an almost instantaneous, non-inactivating steady-state current, $\mathrm{I}_{\mathrm{ss}}[16]$.

We recorded $\mathrm{I}_{\text {to }}$ in the presence of external TEA $(50 \mathrm{mmol} / \mathrm{l})$. Starting from a holding potential (HP) of $-60 \mathrm{mV}$, depolarising pulses to membrane potentials between -30 and $+50 \mathrm{mV}$ were applied at a frequency of $0.1 \mathrm{~Hz}$. The TEA-resistant $\mathrm{I}_{\mathrm{ss}}$ was subtracted. Peak $\mathrm{I}_{\text {to }}$ were normalised to cell capacitance, and are expressed as $\mathrm{pA} / \mathrm{pF}$.

We recorded $\mathrm{I}_{K}$ in the presence of 4 -AP $5 \mathrm{mmol} / \mathrm{l}$, from a $\mathrm{HP}$ of $-120 \mathrm{mV}$; prepulses of $15 \mathrm{~ms}$ of duration to $-40 \mathrm{mV}$ were applied to inactivate $\mathrm{I}_{\mathrm{Na}}$, followed by test pulses between 
-30 and $+50 \mathrm{mV}$. The blocking effect of 4-AP on $\mathrm{I}_{\text {to }}$ shows reverse use-dependence at fast stimulation rates [20]. To avoid the reverse use-dependence, we applied test pulses at a frequency of $0.05 \mathrm{~Hz}$. Peak $\mathrm{I}_{\mathrm{K}}$ were normalised to cell capacitance, and are expressed as $\mathrm{pA} / \mathrm{pF}$.

The steady state current $I_{\mathrm{ss}}$ was studied in the absence of potassium channel blockers. From an HP of $-20 \mathrm{mV}$ to inactivate $I_{\mathrm{Na}}, I_{\text {to }}$ and $I_{K}$, pulses to potentials ranging from -30 to +50 were applied at a frequency of $0.1 \mathrm{~Hz}$. Steady-state $\mathrm{I}_{\mathrm{ss}}$ were normalised to cell capacitance, and are expressed as $\mathrm{pA} /$ $\mathrm{pF}$.

Solutions. To isolated ventricular myocytes we used a normal Tyrode solution of the following composition (in mmol/l): 118 $\mathrm{NaCl}, 5.4 \mathrm{KCl}, 24 \mathrm{NaHCO}_{3}, 1.05 \mathrm{MgCl}_{2}, 0.42 \mathrm{NaH}_{2} \mathrm{PO}_{4}, 20$ dextrose, 20 taurine, $1.8 \mathrm{CaCl}_{2}$, bubbled with $95 \% \mathrm{O}_{2}$ and $5 \%$ $\mathrm{CO}_{2}$ to stabilise the $\mathrm{pH}$ at 7.4. The KB solution contained (in mmol/l): 10 taurine, 70 glutamic acid, 0.5 creatine, 5 succinic acid, 10 dextrose, $10 \mathrm{KH}_{2} \mathrm{PO}_{4}, 20 \mathrm{KCl}, 10$ HEPES-K, 0.2 EGTA-K, pH adjusted to 7.4 with $\mathrm{KOH}$

To elicit cell action potentials, we used normal external solution of the following composition (in mmol/l): $136 \mathrm{NaCl}, 5.4$ $\mathrm{KCl}, 1 \mathrm{MgCl}_{2}, 10$ HEPES-Na, $1.8 \mathrm{CaCl}_{2}, 11$ dextrose, $\mathrm{pH}$ adjusted to 7.4 with $\mathrm{NaOH}$. To measure $\mathrm{Ca}^{+2}$-independent, voltage-activated $\mathrm{K}^{+}$currents, we used bath solutions containing (in mmol/l): $136 \mathrm{NaCl}, 4 \mathrm{KCl}, 1 \mathrm{MgCl}_{2}, 10$ HEPES-Na, 0.5 $\mathrm{CaCl}_{2}, 11$ dextrose, $2 \mathrm{CoCl}_{2}, \mathrm{pH}$ adjusted to 7.4 with $\mathrm{NaOH}$. When 4-AP was added to a solution, $\mathrm{pH}$ was readjusted to 7.4 with $\mathrm{HCl}$. When TEA-Cl was added to a solution, $\mathrm{NaCl}$ was equimolarly substituted by TEA-Cl. The pipette solution was (in mmol/l): $80 \mathrm{~L}$-aspartic acid, $10 \mathrm{KH}_{2} \mathrm{PO}_{4}, 1 \mathrm{MgSO}_{4}, 50 \mathrm{KCl}$, 5 HEPES-K, 3 ATP-Na, 10 EGTA-K, pH adjusted to 7.4 with $\mathrm{KOH}$.

Data analysis. Current traces were analysed using the Clampfit program of pClamp 5.1 software. No leaks or capacitive subtractions were used during the experiment or digital analysis.

Data are expressed as means \pm SEM. Each group was compared with its own control, and statistical significance was calculated using Student's $t$ test, a $P$ value of less than 0.05 was considered as statistically significant. Multiple comparisons were made using ANOVA and Bonferroni's method.

\section{Results}

The morphology of action potentials was clearly changed in myocytes isolated from diabetic hearts compared with control hearts. The duration of the action potentials in cells paced at $1 \mathrm{~Hz}$ was shorter in control cells than in diabetic ones isolated from the same region of the heart (Fig.1). Action potentials from diabetic cells showed a less pronounced phase 1 (early repolarisation) and a longer phase 2 (plateau). The action potentials of a control subendocardial cell was longer than the action potentials of subepicardial or right ventricle cells of diabetic hearts.

Table 1 gives the numerical values of the action potential variables of diabetic and control cells. Neither resting potentials nor action potential amplitudes were changed in diabetic myocytes compared with control cells. The duration of all the action potentials was, however, longer than in control cells
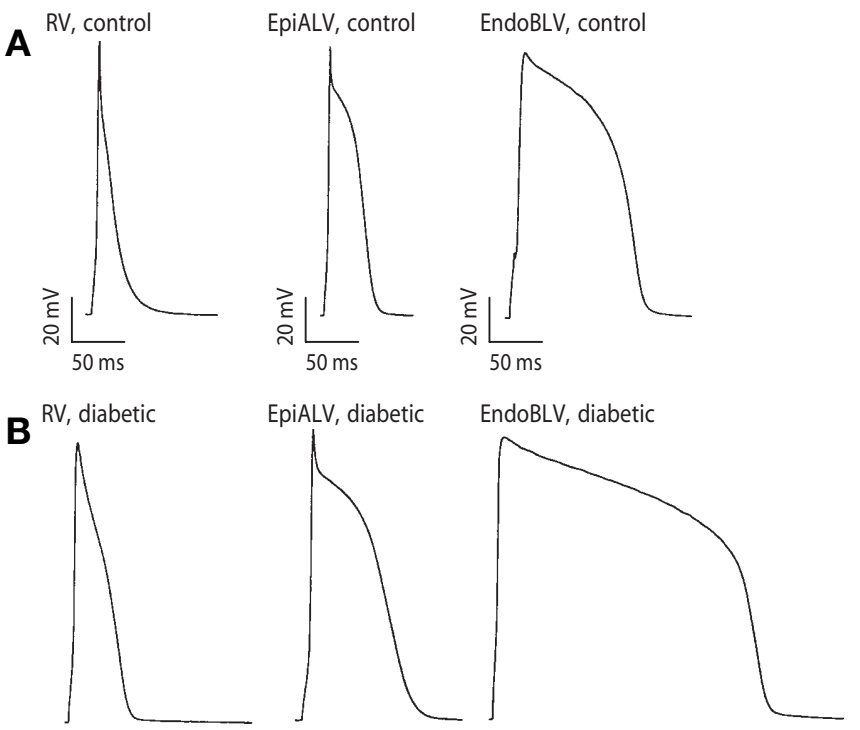

Fig. 1A, B. Action potentials of the three selected regions of the ventricular muscle recorded in control cells $(\mathbf{A})$ and diabetic cells (B)

from the same ventricular region. The less pronounced early repolarisation phase and lengthening in $\mathrm{APD}_{30}$ in all the three regions suggest the involvement of $\mathrm{I}_{\mathrm{to}}$ but the increase in the effect in the $\mathrm{APD}_{50}$ and $\mathrm{APD}_{90}$ suggest the involvement of other currents such as $I_{\mathrm{ss}}$ or $\mathrm{I}_{\mathrm{K}}$ or both. The lengthening in APD induced by diabetes is in EndoBLV greater than in EpiALV and in EpiALV greater than in RV, so the lengthening increases in the regions in which $\mathrm{I}_{\mathrm{K}}$ is more important to repolarisation.

To identify the possible cause of the prolonged action potential duration, we studied the effects of Type I diabetes on $\mathrm{K}^{+}$currents, taking into account regional variability under control conditions. Figure 2 shows current recordings of $\mathrm{I}_{\mathrm{to}}$, in a control and in a diabetic cell, both from the same ventricular regions. In the presence of TEA to block $\mathrm{I}_{\mathrm{K}}$, current traces were elicited by depolarising pulses ranging from -30 to $+50 \mathrm{mV}$, from a holding potential of $-60 \mathrm{mV}$. There was a uniform about $50 \%$ decrease in the density of $I_{t o}$ in each ventricular region (Fig. 2 C). The rate of decay of $\mathrm{I}_{\text {to }}$ was accelerated by diabetes, being $45.73 \pm 1.3 \mathrm{~ms}$ in control and $34.98 \pm 2.3 \mathrm{~ms}$ in diabetic cells $(p<0.01)$.

A possible explanation for the decrease in density of $\mathrm{I}_{\mathrm{to}}$ is a change in the time-dependence of recovery from inactivation. If this were slowed, not all the channels would have sufficient time to recover from inactivation during the interval between successive stimuli. Consequently, the amplitude of the current on the next stimulus would be smaller. To test this possibility, we studied the recovery characteristics of $\mathrm{I}_{\mathrm{to}}$ in the presence of TEA, in control and diabetic cells from RV and EpiBLV, by applying a $150 \mathrm{~ms}$ conditioning prepulse to $+50 \mathrm{mV}$ to inactivate $\mathrm{I}_{\text {to }}$ chan- 
Table 1. Action potential measurements recorded in cells isolated from the right ventricular free wall (RV), subepicardium at the apex of the left ventricle (EpiALV) and subendocardium at the base of the left ventricle (EndoBLV), in healthy and diabetic cells

\begin{tabular}{|c|c|c|c|c|c|c|}
\hline & \multicolumn{2}{|l|}{ RV } & \multicolumn{2}{|l|}{ EpiALV } & \multicolumn{2}{|l|}{ EndoBLV } \\
\hline & $\begin{array}{l}\text { Control } \\
(n=10)\end{array}$ & $\begin{array}{l}\text { Diabetes } \\
(n=14)\end{array}$ & $\begin{array}{l}\text { Control } \\
(n=18)\end{array}$ & $\begin{array}{l}\text { Diabetes } \\
(n=10)\end{array}$ & $\begin{array}{l}\text { Control } \\
(n=9)\end{array}$ & $\begin{array}{l}\text { Diabetes } \\
(n=12)\end{array}$ \\
\hline $\mathrm{RP}(\mathrm{mV})$ & $-85.7 \pm 0.8$ & $-85.3 \pm 1.4$ & $-82.2 \pm 1.4$ & $-85.2 \pm 2.2$ & $-84.7 \pm 0.5$ & $-81.5 \pm 1.5$ \\
\hline $\mathrm{APA}(\mathrm{mV})$ & $124 \pm 8.1$ & $110.6 \pm 2.6$ & $114.6 \pm 2.7$ & $112.5 \pm 8.1$ & $124.2 \pm 4.1$ & $117.1 \pm 4.8$ \\
\hline $\mathrm{APD}_{30}(\mathrm{~ms})$ & $17.6 \pm 2.5$ & $66.4 \pm 13.7^{b}$ & $46.3 \pm 10.1$ & $84.7 \pm 28.7$ & $73.8 \pm 14.2$ & $194.9 \pm 37.9^{b}$ \\
\hline $\mathrm{APD}_{50}(\mathrm{~ms})$ & $45.3 \pm 3$ & $96.1 \pm 14.7^{b}$ & $57 \pm 11.5$ & $128.4 \pm 36.1^{\mathrm{a}}$ & $98.1 \pm 15.7$ & $264.6 \pm 45.9^{b}$ \\
\hline $\mathrm{APD}_{90}(\mathrm{~ms})$ & $66.4 \pm 3.6$ & $119 \pm 14.5^{\mathrm{b}}$ & $74.9 \pm 11.9$ & $168.6 \pm 46^{\mathrm{b}}$ & $120.7 \pm 16.8$ & $298.6 \pm 48.7^{b}$ \\
\hline
\end{tabular}

$\mathrm{RP}=$ resting potential, $\mathrm{APD}_{30,50,90}=$ action potential duration at 30,50 and $90 \%$ of repolarisation, respectively. ${ }^{\mathrm{a}} p<0.05$, ${ }^{\mathrm{b}} p<0.01$

nels, followed by a progressively increased interval by a test pulse to $+50 \mathrm{mV}$ (Fig. 3). There was no appreciable variation between the time-dependence of recovery in the two types of cells. The recovery time constant, $\tau$, was $38.6 \pm 2.6$ and $41.44 \pm$ $3.61 \mathrm{~ms}$ in control and diabetic cells, respectively. The small amplitude of $\mathrm{I}_{\text {to }}$ in EndoBLV in diabetic cells precluded a relaible study of $\mathrm{I}_{\text {to }}$ recovery from inactivation.

In the presence of 4-AP to block $\mathrm{I}_{\mathrm{to}}$, the delayed rectifier current, $\mathrm{I}_{\mathrm{K}}$, was elicited by applying depolarising pulses ranging from -30 to $+50 \mathrm{mV}$, from a holding potential of $-120 \mathrm{mV}$, with a short prepulse to $-40 \mathrm{mV}$ to inactivate $\mathrm{Na}^{+}$current. The density of $\mathrm{I}_{\mathrm{K}}$ was decreased in diabetic myocytes but the decrease was not uniform (Fig.4). The decrease was

Fig. 2 A, B. Current traces of a current-voltage protocol of the transient outward current elicited in $(\mathbf{A})$ a control cell from the right ventricle in the presence of TEA, $(\mathbf{B})$ a diabetic cell from the right ventricle. $\mathbf{C ~ I}_{\text {to }}$ current amplitudes at $+50 \mathrm{mV}$ in each one of the three regions under study, in control cells $(\square)$ and in diabetic cells $(\square)$. ${ }^{*} p<0.05, * * p<0.01$
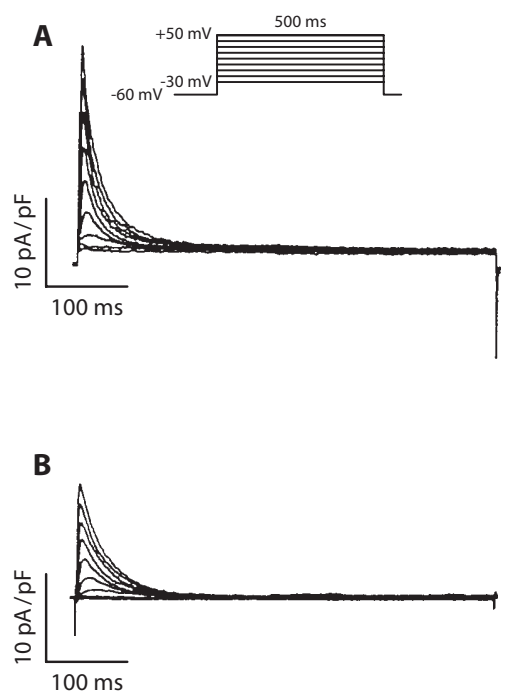

about $10 \%$ in the right ventricle, about $30 \%$ in the subepicardium at the apex of the left ventricle and about $48 \%$ in the subendocardium at the base of the left ventricle.

In diabetic myocytes, $\mathrm{I}_{\mathrm{ss}}$ was decreased in all regions of the heart in diabetic cells compared with control cells (Fig. 5). We elicited $\mathrm{I}_{\mathrm{ss}}$ by applying depolarising pulses, ranging from -30 to $+50 \mathrm{mV}$, from a holding potential of $-20 \mathrm{mV}$. At this holding potential, both $\mathrm{I}_{\mathrm{to}}$ and $\mathrm{I}_{\mathrm{K}}$ are fully inactivated. Once again, the decrease was uniform and stood at about $40 \%$ in each of the three regions studied.

The decreases in the densities of $\mathrm{I}_{\text {to }}$ and $\mathrm{I}_{\mathrm{K}}$ could be caused by a change in the voltage-dependence of inactivation. For example, if shifted to a more negative membrane potential, the result would be fewer channels available to conduct current at the resting potential. To test this possibility, we studied the inactivation characteristics of these currents using a typical two pulse protocol, with a $10 \mathrm{~s}$ prepulse ranging from -120 to $0 \mathrm{mV}$, followed by a $50 \mathrm{~ms}$ test pulse to $+50 \mathrm{mV}$. Peak current amplitudes at $+50 \mathrm{mV}$ were plotted against the voltage of the prepulse and fitted to the equation:

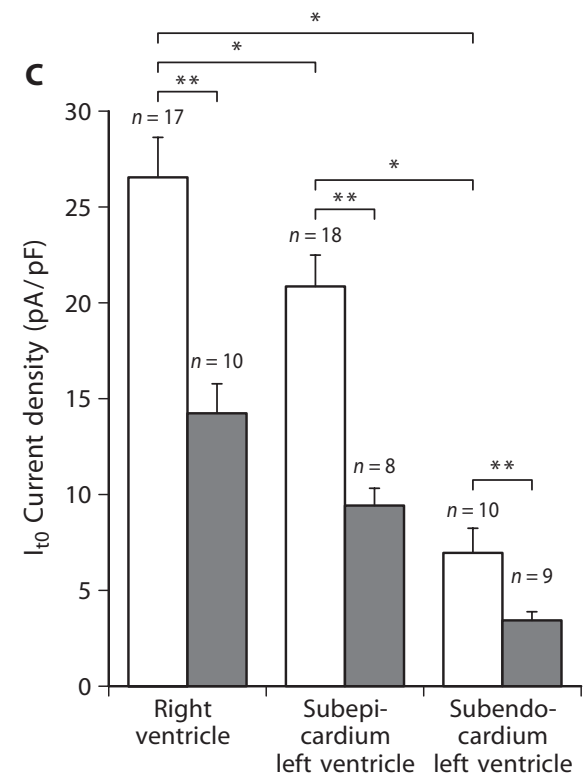



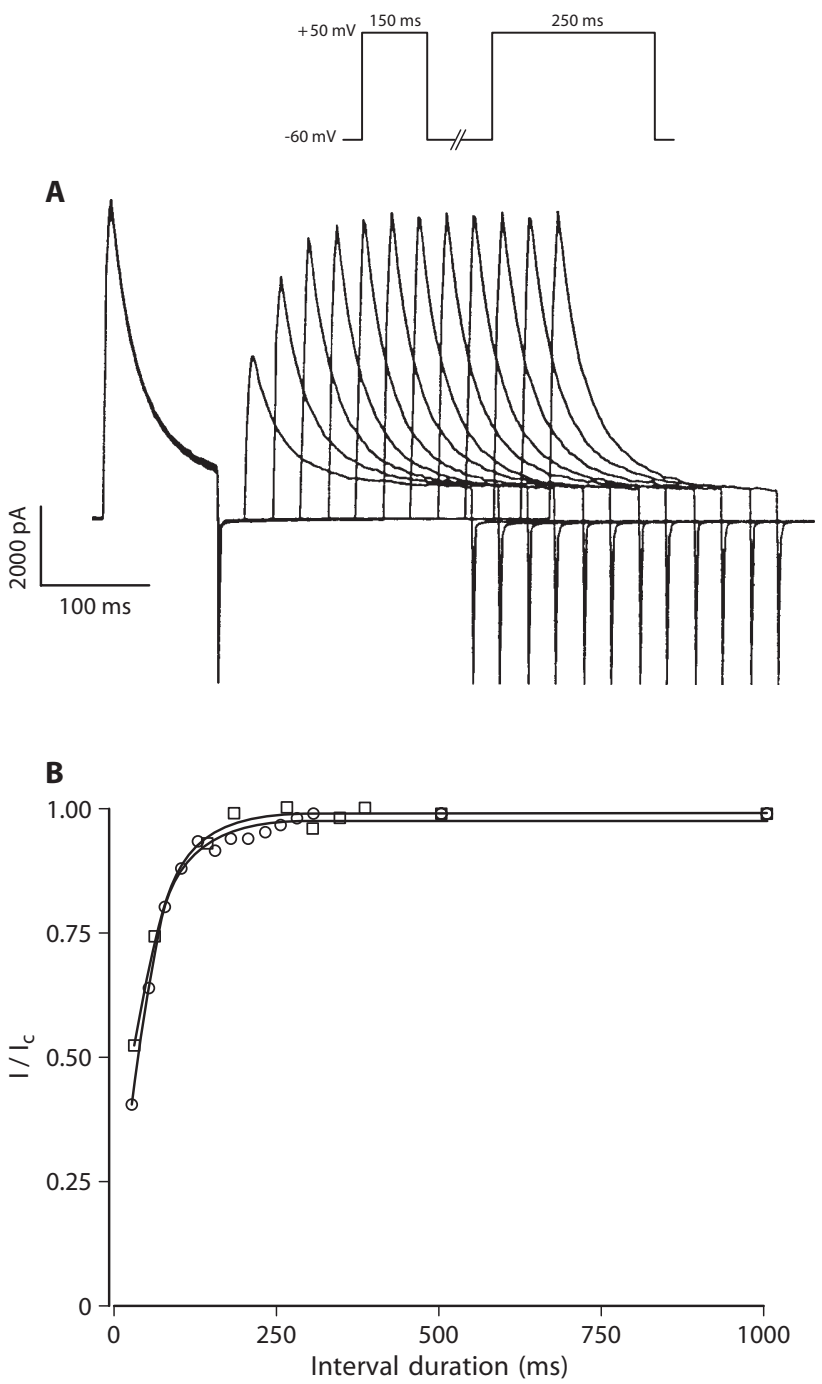

Fig.3. A Current recordings of an $I_{\text {to }}$ inactivation recovery protocol of a control cell from the right ventricle in the presence of TEA. B Recovery from inactivation in a normal $(\bigcirc)$ and a diabetic $(\square)$ cell. Each point is the proportion between the amplitude between the control pulse and the prepulse, plotted with respect to interval time. The points were fitted to the equation: $\left.\mathrm{I} / \mathrm{I} c=\mathrm{A}\left[1-\mathrm{e}^{(-\mathrm{t} / \tau}\right)\right]$
$\mathrm{I} / \mathrm{I}_{\max }=\mathrm{A}_{1} /\left[1+\mathrm{e}^{(\mathrm{V}-\mathrm{Vh} 1) / \mathrm{S} 1}\right]+\mathrm{A}_{2} /\left[1+\mathrm{e}^{(\mathrm{V}-\mathrm{Vh} 2) / \mathrm{S} 2}\right]+\mathrm{R}$

The first and second components correspond to $\mathrm{I}_{\mathrm{K}}$ and $\mathrm{I}_{\mathrm{to}}$ inactivation, and " $\mathrm{R}$ " corresponds to the noninactivating $\mathrm{I}_{\mathrm{ss}}[15,21]$. Figure 6 shows the change in the proportion of relative amplitudes with respect to the others, although there was no change in half-inactivation voltages $\left(\mathrm{V}_{\mathrm{h} 1}\right.$ and $\left.\mathrm{V}_{\mathrm{h} 2}\right)$ or in slope factor $\left(\mathrm{S}_{1}\right.$ and $S_{2}$ ) (Table 2). The relative amplitudes of $I_{K}$ and $\mathrm{I}_{\text {to }}$ (Fig. 4C and 2C) do not show statistically significant differences to the relative amplitudes $\mathrm{A}_{1}$ and $\mathrm{A}_{2}$.

There was no variation between the two experimental groups in any of the three ventricular regions in the density of the inward rectifier current, $\mathrm{I}_{\mathrm{K} 1}$, elicited by hyperpolarising pulses ranging from -120 to $-40 \mathrm{mV}$, from a holding potential of $-40 \mathrm{mV}$. (Fig. 7)

The peak amplitude values of each current in each of the regions under study are set out in Table 3.

\section{Discussion}

We found that experimental Type I diabetes induced by streptozotocin produced an increase in APD in rat ventricular myocytes. We also found that the APD increase was different in the three regions studied, RV, EpiALV and EndoBLV. Type I diabetes increased APD measured at $90 \%$ of repolarisation $80 \%, 125 \%$ and $148 \%$, respectively. Previous studies have also found increases in APD; no comparisons were, however, made between the different regions of the ventricle $[9,13]$. These results suggest that the epicardial-endocardial differences in APD are increased in Type I diabetic rats. Therefore, Type I diabetic rats can have a lengthened Q-T interval, without flat or inverted $\mathrm{T}$ wave in the electrocardiogram. Type I diabetic patients present a lengthened Q-T interval $[1,2,3]$. Depression of the S-T segment has been observed in derivations V2 and V6 only in patients with Type II diabetes during hypoglycaemic episodes [22].

The regional disparity of $\mathrm{K}^{+}$currents is responsible for some of the well-known differences in the duration

Table 2. Inactivation variables of $\mathrm{I}_{\mathrm{K}}, \mathrm{I}_{\text {to }}$ and $\mathrm{I}_{\mathrm{ss}}$ (first component, second component and R, respectively)

\begin{tabular}{|c|c|c|c|c|c|c|}
\hline & \multicolumn{2}{|l|}{$\mathrm{RV}$} & \multicolumn{2}{|l|}{ EpiALV } & \multicolumn{2}{|l|}{ EndoBLV } \\
\hline & $\begin{array}{l}\text { Control } \\
(n=13)\end{array}$ & $\begin{array}{l}\text { Diabetes } \\
(n=13)\end{array}$ & $\begin{array}{l}\text { Control } \\
(n=10)\end{array}$ & $\begin{array}{l}\text { Diabetes } \\
(n=10)\end{array}$ & $\begin{array}{l}\text { Control } \\
(n=13)\end{array}$ & $\begin{array}{l}\text { Diabetes } \\
(n=20)\end{array}$ \\
\hline $\mathrm{V}_{\mathrm{h} 2}$ & $-37.2 \pm 1.5$ & $-36.6 \pm 0.9$ & $-35.6 \pm 0.9$ & $-38.1 \pm 0.8$ & $-34.8 \pm 1.6$ & $-36.9 \pm 2.8$ \\
\hline $\mathrm{S}_{1}$ & $8.8 \pm 0.7$ & $9.8 \pm 1.05$ & $10.0 \pm 1.3$ & $9.5 \pm 1$ & $11.2 \pm 1.4$ & $10.9 \pm 0.8$ \\
\hline $\mathrm{S}_{2}$ & $3.4 \pm 0.1$ & $4 \pm 0.1$ & $3.7 \pm 0.1$ & $4.3 \pm 0.4$ & $3.5 \pm 0.4$ & $5.3 \pm 1.2$ \\
\hline $\mathrm{A}_{1}$ & $10.4 \pm 0.8$ & $9.2 \pm 1.06$ & $9.1 \pm 1.1$ & $8.04 \pm 1.3$ & $9.4 \pm 0.8$ & $6.9 \pm 0.7^{\mathrm{a}}$ \\
\hline
\end{tabular}

There are no variations in half inactivation voltages $\left(\mathrm{V}_{\mathrm{h}}\right)$ and voltage dependencies of inactivation (S) between healthy and diabetic cells. The only variations are in the amplitudes of the three current components $(\mathrm{A}, \mathrm{R}){ }^{\mathrm{a}} p<0.05,{ }^{\mathrm{b}} p<0.01$ 


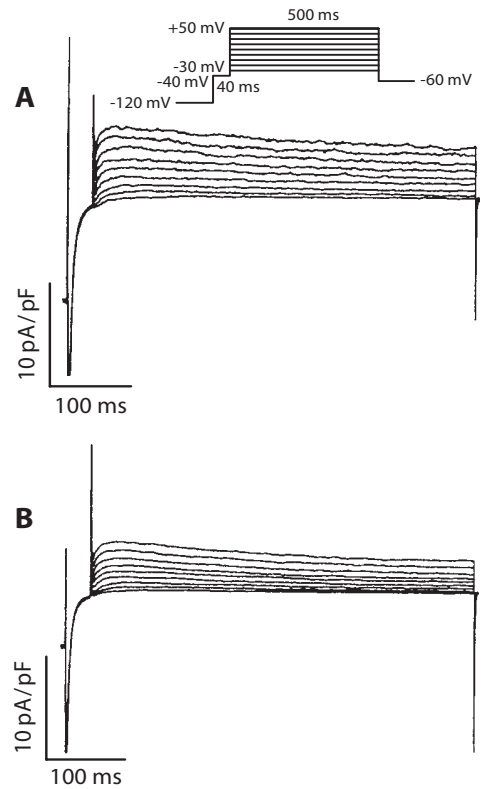

Fig. 4A, B. Recordings of a current voltage protocol of the delayed rectifier current of $(\mathbf{A})$ a control cell and (B) a diabetic cell from the subepicardium of the apex of the left ventricle in the presence of 4-AP. C $\mathrm{I}_{\mathrm{K}}$ current amplitudes at $+50 \mathrm{mV}$ in each one of the three regions under study, in healthy cells $(\square)$ and in diabetic cells $(\square)$. ${ }^{*} p<0.05,{ }^{*} * p<0.01$

of the rat ventricular action potentials $[10,11,21]$. Therefore, the relative participation of the currents to the repolarisation process could differ in the differ-

Fig.5A, B. Recordings of a current voltage protocol of the sustained current in $(\mathbf{A})$ a control cell and (B) a diabetic cell from the subendocardium of the base of the left ventricle. C I ${ }_{\mathrm{ss}}$ current amplitudes at $+50 \mathrm{mV}$ in each one of the three regions under study, in healthy cells $(\square)$ and in diabetic cells (更). $* p<0.05, * * p<0.01$
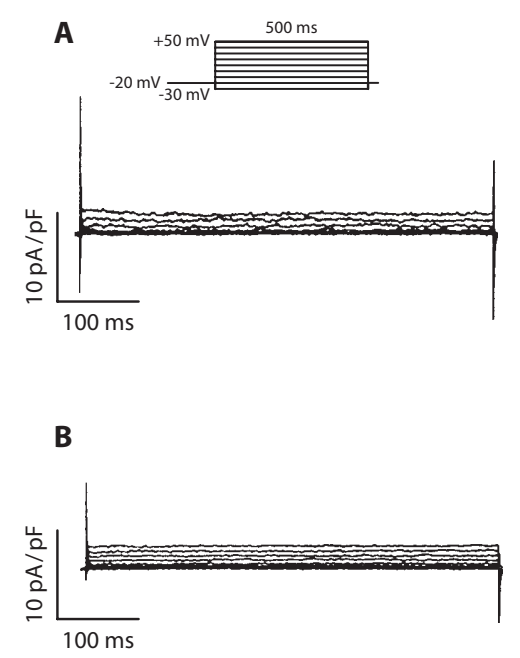

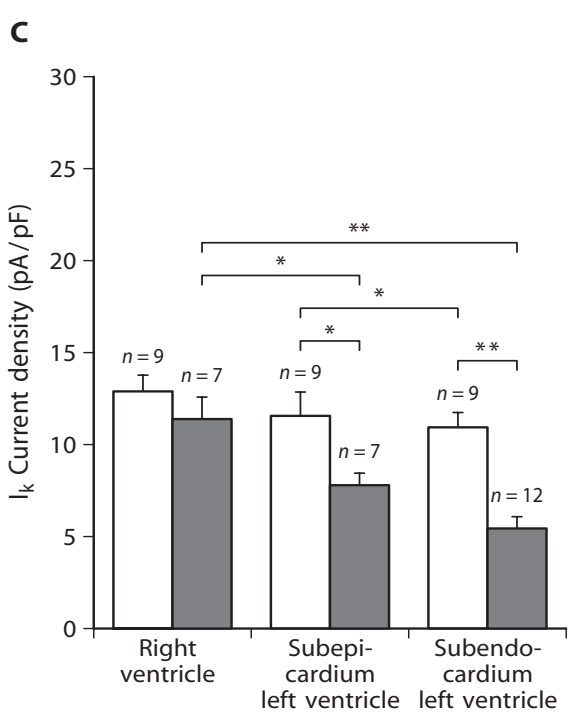

ent regions, thus, $\mathrm{I}_{\text {to }}$ participation in control hearts is in RV greater than in EpiALV and in EpiALV greater than in EndoBLV. Because $I_{\text {to }}$ current inactivation is a slow process $(45.73 \pm 1.3 \mathrm{~ms})$ this current participates not only in phase 1 , but also in phase 2 . Thus, in regions with high $\mathrm{I}_{\text {to }}$ current density, net outward current is greater, producing a short plateau. Moreover, a larger $\mathrm{I}_{\text {to }}$ produces a more pronounced early repolarisation phase, thus provoking calcium current deactivation and $I_{K 1}$ activation because $I_{K 1}$ activates when membrane potential repolarises to $-30 \mathrm{mV}$ [23].

Especially noteworthy is the regional reduction pattern of the depolarisation-activated, calciumindependent outward $\mathrm{K}^{+}$currents by diabetes. In all three ventricular regions studied $\mathrm{I}_{\text {to }}$ was reduced by $50 \%$ and $\mathrm{I}_{\mathrm{ss}}$ was reduced by $40 \%$. In RV, $\mathrm{I}_{\mathrm{K}}$ was reduced $10 \%$, in EpiALV $32 \%$ and in EndoBLV $48 \%$. As previously reported, $\mathrm{I}_{\mathrm{K} 1}$ was not affected by diabetes $[9,13]$. From these results we suggest that the re-

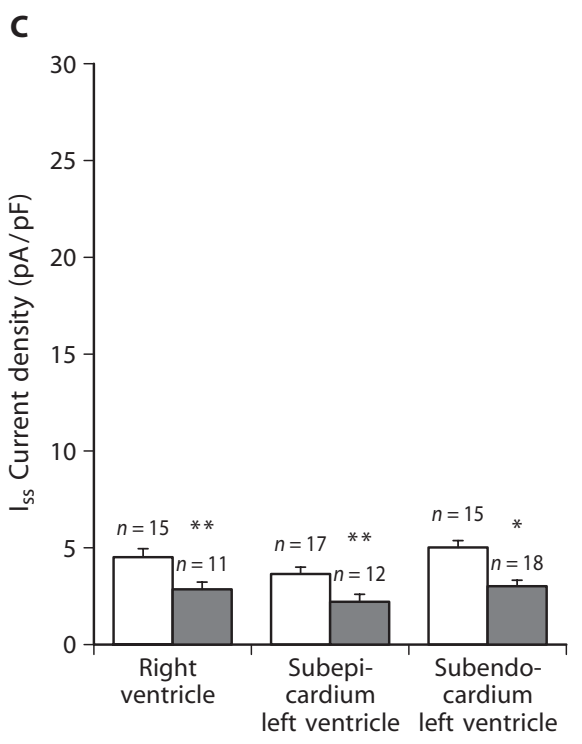



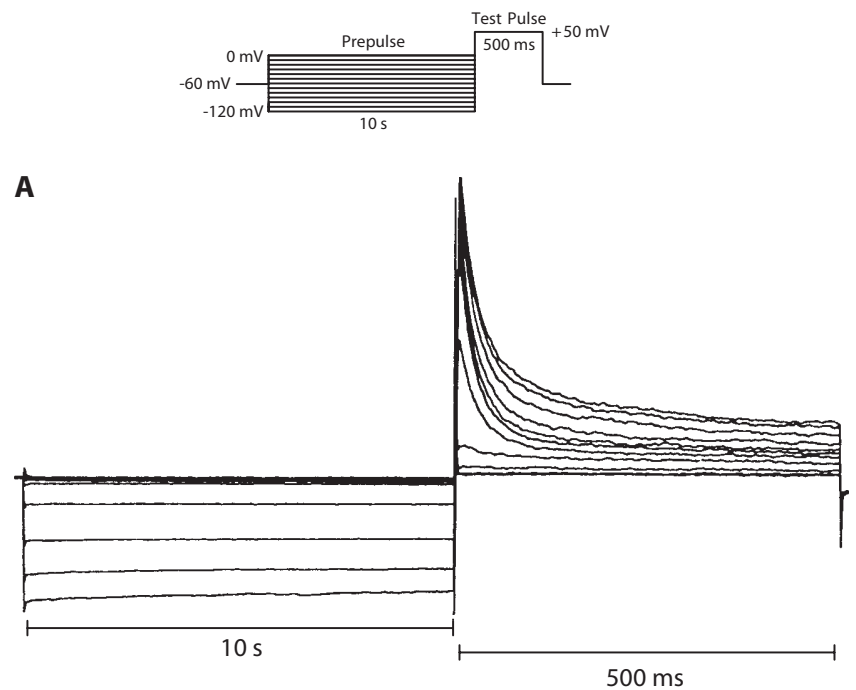

B

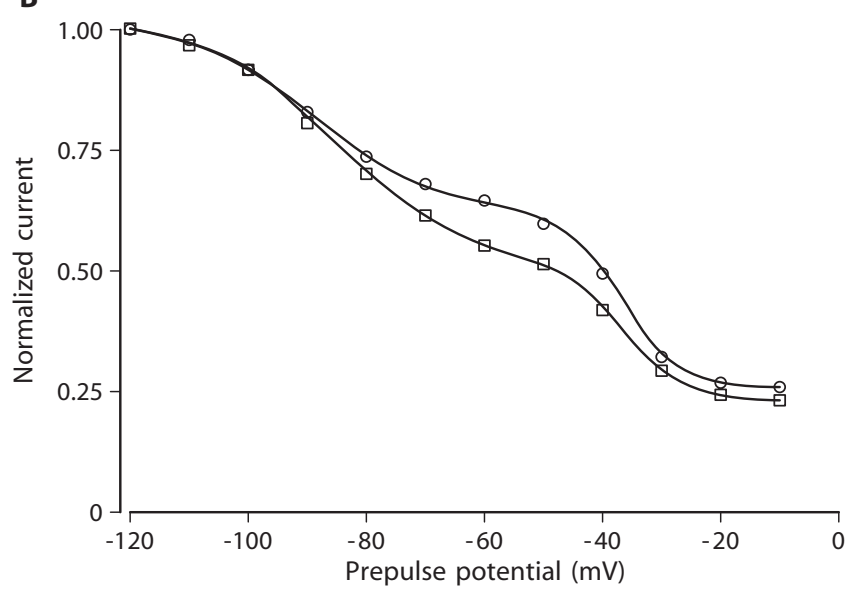

Fig. 6. A Current recordings of an inactivation protocol of a control cell from the subepicardium of the apex of the left ventricle. B Graphic representation of the inactivation protocol in a control $(\bigcirc)$ and a diabetic $(\square)$ cell. Each point is the peak current amplitude divided by the maximum peak amplitude at $+50 \mathrm{mV}$, with respect to the prepulse potential. Points were fitted to a double Boltzmann equation: $\mathrm{I} / \mathrm{I}_{\max }=\mathrm{A}_{1} /[1+$ $\left.\mathrm{e}^{(\mathrm{V}-\mathrm{Vh} 1) / \mathrm{S} 1}\right]+\mathrm{A}_{2} /\left[1+\mathrm{e}^{(\mathrm{V}-\mathrm{Vh} 2) / \mathrm{S} 2}\right]+\mathrm{R}$ gional differences in APD lengthening induced by experimental diabetes are explained by the uneven decrease in $\mathrm{I}_{\mathrm{K}}$ and the differences in the relative contribution of the depolarisation-activated outward currents to the repolarisation process.

From our results, we can see that there are no regional differences in the inactivation characteristics of $\mathrm{I}_{\mathrm{to}}$ and $\mathrm{I}_{\mathrm{K}}$ in control cells, as previously described in rat [21] and rabbit ventricles [24]. Half inactivation voltages and slope factors are not changed by Type I diabetes on $\mathrm{I}_{\mathrm{to}}$ inactivation [13].

It has been found [14] that $I_{\text {to }}$ reduction (measured as total peak outward current) by diabetes was more pronounced in EpiALV than EndoBLV. From their results (Fig. 9A of ref. [14]) we measured a reduction of approximately $36 \%$ in subepicardium and $24 \%$ in subendocardium. In this study, we found a greater reduction in $\mathrm{I}_{\text {to }}$ in the three regions studied. We did our experiments, however, 4 weeks as opposed to 6 or 7 days [14] after the injection of streptozotocin. The earlier study also reported that the attenuation of the steady-state "pedestal" current was similar in subepicardial and subendocardial myocytes [14]. We measured, however, from their results (Fig. 9B and 9C of ref. [14]) a reduction of approximately $40 \%$ in subepicardial and $60 \%$ in subendocardial cells. In this study, we dissected out the two components of the "pedestal" current, $I_{K}$ and $I_{s s}$. Until now these two currents were always recorded together $[15,16]$. We found $I_{s s}$ was uniformly reduced in the three regions studied but $I_{K}$ reduction showed a regional pattern, despite showing no regional variation in healthy heart muscle.

Studying the recovery from inactivation of $\mathrm{I}_{\text {to }}$ in the presence of TEA to block $I_{K}$ [15] in RV and EpiALV, we found that the recovery process was monoexponential with a $\tau$ of $38.6 \pm 2.6 \mathrm{~ms}$. The recovery from inactivation of $\mathrm{I}_{\mathrm{to}}$ was not modified by diabetes. In previous results [14] the recovery from inactivation of $\mathrm{I}_{\mathrm{to}}$ was studied in the presence of $\mathrm{I}_{\mathrm{K}}$. Under those experimental conditions, the recovery process was fitted by a biexponential function, with $\tau 1$ value similar to the single $\tau$ found in our study and another study[15] blocking $\mathrm{I}_{\mathrm{K}}$. The $\tau 2$ value found previously [14] was approximately 50 times greater than $\tau 1$ and

Table 3. Peak amplitude at $+50 \mathrm{mV}$ of $\mathrm{I}_{\mathrm{to}}, \mathrm{I}_{\mathrm{ss}}$ and $\mathrm{I}_{\mathrm{K}}$, and at $-120 \mathrm{mV}$ of $\mathrm{I}_{\mathrm{K} 1}$, in $\mathrm{pA} / \mathrm{pF}$, in healthy and diabetic cells

\begin{tabular}{|c|c|c|c|c|c|c|}
\hline & \multicolumn{2}{|l|}{$\mathrm{RV}$} & \multicolumn{2}{|l|}{ EpiALV } & \multicolumn{2}{|l|}{ EndoBLV } \\
\hline & Control & Diabetes & Control & Diabetes & Control & Diabetes \\
\hline$\overline{\mathrm{I}_{\mathrm{K} 1}}$ & $\begin{array}{l}-18.1 \pm 0.8 \\
(n=16)\end{array}$ & $\begin{array}{l}-18.2 \pm 0.7 \\
(n=10)\end{array}$ & $\begin{array}{l}-15.9 \pm 1.2 \\
(n=13)\end{array}$ & $\begin{array}{l}-16.7 \pm 1 \\
(n=13)\end{array}$ & $\begin{array}{l}-16.9 \pm 1 \\
(n=16)\end{array}$ & $\begin{array}{l}-19.3 \pm 1 \\
(n=19)\end{array}$ \\
\hline $\mathrm{I}_{\text {to }}$ & $\begin{array}{l}26.3 \pm 2.2 \\
(n=17)\end{array}$ & $\begin{array}{l}14.07 \pm 1^{\mathrm{b}} \\
(n=10)\end{array}$ & $\begin{array}{l}20.7 \pm 1.6 \\
(n=18)\end{array}$ & $\begin{array}{l}9.3 \pm 0.9^{\mathrm{b}} \\
(n=8)\end{array}$ & $\begin{array}{l}7.0 \pm 1 \\
(n=10)\end{array}$ & $\begin{array}{l}3.4 \pm 0.4^{\mathrm{b}} \\
(n=9)\end{array}$ \\
\hline $\mathrm{I}_{\mathrm{ss}}$ & $\begin{array}{l}4.5 \pm 0.4 \\
(n=15)\end{array}$ & $\begin{array}{l}2.8 \pm 0.3^{\mathrm{b}} \\
(n=11)\end{array}$ & $\begin{array}{l}3.65 \pm 0.3 \\
(n=17)\end{array}$ & $\begin{array}{l}2.2 \pm 0.3^{\mathrm{b}} \\
(n=12)\end{array}$ & $\begin{array}{l}5.0 \pm 0.37 \\
(n=15)\end{array}$ & $\begin{array}{l}3.0 \pm 0.3^{\mathrm{a}} \\
(n=18)\end{array}$ \\
\hline
\end{tabular}

${ }^{\mathrm{a}} p<0.05,{ }^{\mathrm{b}} p<0.01$ 


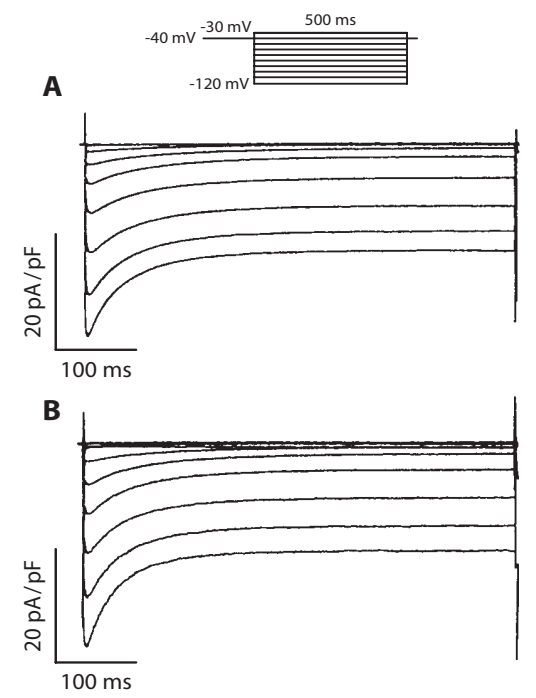

Fig. 7A, B. Recordings of a current voltage protocol of the inward rectifier current in $(\mathbf{A})$ a control cell and $(\mathbf{B})$ a diabetic cell from the subepicardium of the apex of the left ventricle. C $\mathrm{I}_{\mathrm{K} 1}$ current amplitudes at $-120 \mathrm{mV}$ in each one of the three regions under study, in healthy cells $(\square)$ and in diabetic cells (ם)

similar to the time constant of the recovery from inactivation of $\mathrm{I}_{\mathrm{K}}[15]$. Small differences were found in $\tau 1$ between subendocardial $(36.5 \mathrm{~ms})$ and subepicardial (95 ms) myocytes; no deviations were, however, provided to deduce possible statistical significance. The most striking difference between control and diabetic myocytes previously found [14] on the recovery process on subendocardial and subepicardial left ventricular myocytes was an increase in the relative participation of the slow component to the recovery process and $\tau 1$ of subendocardial cells was shortened $(95 \mathrm{~ms}$ vs $41.6 \mathrm{~ms}$ ). This suggests that diabetes increases the relative participation of $I_{K}$ to the total inactivating current. This is consistent with our own findings that diabetes produced a much larger reduction on $\mathrm{I}_{\text {to }}$ than on $\mathrm{I}_{\mathrm{K}}$, mainly in RV and EpiALV myocytes.

The apparent discrepancies between earlier results $[12,14]$ and our results seem to be explained by differences in the method used to dissect out the current components. In those studies [12, 14] experiments were done using an external solution in which all the depolarisation-activated current components $\left(\mathrm{I}_{\mathrm{to}}, \mathrm{I}_{\mathrm{K}}\right.$ and $\left.I_{s s}\right)$ were present $[15,16]$. The $I_{\text {to }}$ amplitude was measured by two methods: 1) as the peak amplitude relative to zero current and 2) the difference between the peak and steady-state current measured at the end of the depolarising pulse. As discussed by those authors [14] the first method can pose problems. To validate the use of the difference in peak and steady state current as a measure of $I_{\text {to }}$, it should be assumed that $I_{K}$ is instantaneous and non-inactivating. It has been shown, however, that $\mathrm{I}_{\mathrm{K}}$ activates about 10 -fold

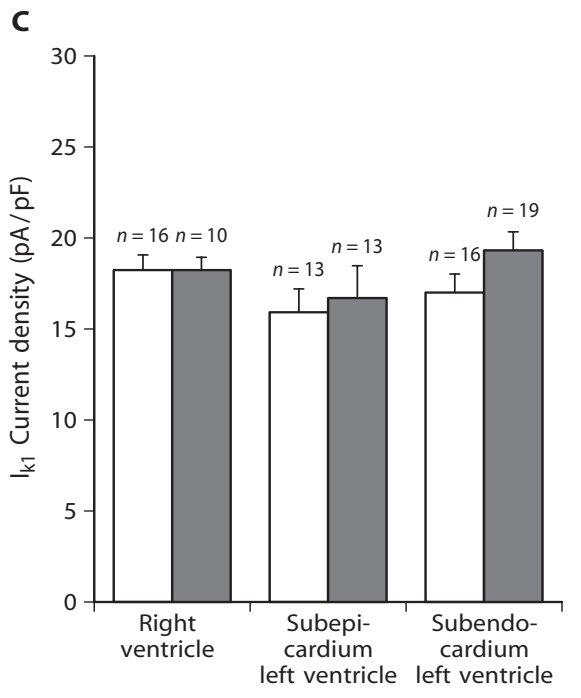

and inactivates about 30 -fold more slowly than $\mathrm{I}_{\text {to }}$ [15]. In our experiments, $I_{\text {to }}$ was measured in the presence of TEA in the external solution to block $\mathrm{I}_{\mathrm{K}}$. It has been shown that $I_{t o}$ is insensitive to external TEA and $\mathrm{I}_{\mathrm{K}}$ block is voltage-dependent and time-independent [15]. The possibility exists, however, that undescribed modifications of external TEA on one of the depolarisation-activated current components in rat ventricular myocytes could affect the current dissection method.

Our results do not enable direct evidence on the mechanism of the Type I diabetes-induced decrease in the depolarisation-activated outward $\mathrm{K}^{+}$currents to be obtained. The lack of effect on the voltagedependence and time-dependence of recovery from current inactivation suggests, however, that the biophysical properties of the channels are unchanged in control and diabetic rats. Thus, the reduction in whole-cell could be due to a change in regulatory factors, to an accumulation of amphiphilic fatty acids such as palmitoyl-carnitine or palmitoyl-CoA, which reduces $I_{t o}$ current amplitude [25], or to a smaller number of channels. It seems that $\mathrm{I}_{\mathrm{to}}$ is a heteromultimer composed by the Kv4.2 and Kv4.3 cloned channels [26]. The inactivation time constant of Kv4.2 is $200 \mathrm{~ms}$ at $+50 \mathrm{mV}$ and that of Kv4.3 is $25 \mathrm{~ms}$ [27, 28]. The acceleration in $I_{t o}$ current inactivation caused by diabetes could be explained by a higher reduction in the Kv4.2 subunit expression. It is clear that additional studies should be done, analysing possible changes induced by diabetes in the expression at the mRNA and protein expression level of the different subunits that underlie these conductance pathways.

In conclusion, experimental diabetes increases APD in rat ventricular myocytes. The increase is dependent on the region studied (EndoBLV $>$ EpiALV $>$ RV). Diabetes does not affect $\mathrm{I}_{\mathrm{K} 1}$, uniformly decreases $I_{\text {to }}$ and $I_{s s}$, and unevenly decreases $I_{K}$ (EndoBLV > EpiALV > RV) without modifying the 
voltage-dependence of the currents. The regional differences in APD increases are possible explained by an uneven decrease in $I_{K}$ and the relative participation of the current components to the action potential repolarisation process in the different regions studied.

These changes could explain the increased predisposition of these patients to episodes of ventricular arrhythmia. The prolongation of the APD causes the cell to remain longer at the depolarised plateau potential. This favours the theory that during this long plateau phase, the inactivated $\mathrm{Ca}^{+2}$ channels have sufficient time to become reactivated and reopen, thus provoking the renewed depolarisation of the cell, which could be one of the possible causes of the frequent appearance of afterpotentials in these patients. Type I diabetes accentuates the regional differences found in healthy hearts, so there are changes in the repolarisation sequence, which could cause changes in the S-T segment and in the T wave of the electrocardiogram, provoking the appearance of re-entry circuits capable of inducing the appearance of ventricular arrhythmias.

Acknowledgements. The authors wish to thank Dr. E. Garcia for her help in glucose determinations. This work was supported by CONACyT (Mexico) grant no 3729P-M to J.A. S-Ch., and by G. V. (PI97/37) and F. I. S. (98/0028-02) grants to O.C.O. Casis was supported by a grant from the F.I.D.E.C.

\section{References}

1. Kahn JK, Sisson JC, Vinik AI (1987) QT interval prolongation and sudden cardiac death in diabetic autonomic neuropathy. J Clin Endocrinol Metab 64: 751-754

2. Sivieri R, Veglio M, Chinaglia A, Scaglione P, CavalloPerin P (1993) Prevalence of QT prolongation in a type I diabetic population and its association with autonomic neuropathy. The Neuropathy Study Group of the Italian Society for the Study of Diabetes. Diabet Med 10: 920-924

3. Veglio M, Chinaglia A, Borra M, Perin PC (1995) Does abnormal QT interval prolongation reflect autonomic dysfunction in diabetic patients? QTc interval measures versus standardised tests in diabetic autonomic neuropathy. Diabet Med 12: 302-306

4. Tong NW, Yang TG, Liang JZ (1993) Ventricular late potentials in patients with diabetes mellitus. Chung Hua Nei Ko Tsa Chih 32: 464-466

5. Robillon JF, Sadoul JL, Jullien D, Morand P, Freychet P (1994) Abnormalities suggestive of cardiomyopathy in patients with type II diabetes of relatively short duration. Diabetes Metab 20: 473-480

6. Celiker A, Akinci A, Ozin B (1994) The signal-averaged electrocardiogram in diabetic children. Int. J Cardiol 44: 271-274

7. Sauviat MP, Feuvray D (1986) Electrophysiological analysis of the sensitivity to calcium in ventricular muscle from alloxan diabetic rats. Basic Res Cardiol 81: 489-496

8. Nobe S, Aomine M, Arita M, Ito S, Takaki R (1990) Chronic diabetes mellitus prolongs action potential duration of rat ventricular muscles: circumstantial evidence for impaired $\mathrm{Ca}^{2+}$ channel. Cardiovasc. Res. 24: 381-389
9. Jourdon P, Feuvray D (1993) Calcium and potassium currents in ventricular myocytes isolated from diabetic rats. $\mathrm{J}$ Physiol (Lond.) 470: 411-429

10. Clark RB, Bouchard RA, Salinas-Stefanon E, SanchezChapula J, Giles WR (1993) Heterogeneity of action potential waveforms and potassium currents in rat ventricle. Cardiovasc Res 27: 1795-1799

11. Watanabe T, Delbridge LM, Bustamante JO, McDonald TF (1983) Heterogeneity of the action potential in isolated rat ventricular myocytes and tissue. Circ. Res. 52: 280-290

12. Shimoni Y, Firek L, Severson D, Giles W (1994) Shortterm diabetes alters $\mathrm{K}^{+}$currents in rat ventricular myocytes. Circ Res 74: 620-628

13. Magyar J, Rusznak Z, Szentesi P, Szucs G, Kovacs L (1992) Action potentials and potassium currents in rat ventricular muscle during experimental diabetes. J Mol Cell Cardiol 24: 841-853

14. Shimoni Y, Severson D, Giles W (1995) Thyroid status and diabetes modulate regional differences in potassium currents in rat ventricle. J Physiol (Lond) 488: 673-688

15. Apkon M, Nerbonne JM (1991) Characterization of two distinct depolarization-activated $\mathrm{K}^{+}$currents in isolated adult rat ventricular myocytes. J Gen Physiol. 97: 973-1011

16. Scamps F (1996) Characterization of a $\beta$-adrenergically inhibited $\mathrm{K}^{+}$current in rat cardiac ventricular cells. J Physiol (Lond), 491: 81-97

17. Xu Z, Patel KP, and Rozanski GJ (1996) Metabolic basis of decreased transient outward $\mathrm{K}^{+}$current in ventricular myocytes from diabetic rats. Am J Physiol 271: H2190-H2196

18. Isenberg G, Klockner U (1982) Calcium tolerant ventricular myocytes prepared by preincubation in a "KB Medium". Pflügers Arch 395: 6-18

19. Hamill OP, Marty A, Neher E, Sakmann B, Sigworth FJ (1981) Improved patch-clamp techniques for highresolution current recording from cells and cell free membrane patches. Pflügers Arch 391: 85-100

20. Campbell DL, Qu Y, Rasmusson LL, Strauss HC (1993) The calcium independent transient outward current in isolated ferret right ventricular myocytes: II. Closed state reverse use-dependent block by 4-aminopyridine. J Gen Physiol 101: 603-626

21. Casis O, Iriarte MM, Gallego M, Sánchez-Chapula JA (1998) Differences in regional distribution of $\mathrm{K}^{+}$current densities in rat ventricle. Life Sci 63: 391-400

22. Lindstrom T, Jorfeldt L, Tegler L, Arnqvist HJ (1992) Hypoglicemia and cardiac arrhythmias in patients with type II diabetes mellitus. Diabet Med 9: 536-541

23. Shimoni Y, Clark RB, Giles WR (1992) Role of an inwardly rectifying potassium current in rabbit ventricular action potential. J Physiol (Lond) 448: 709-727

24. Fedida D, Giles WR (1991) Regional variations in action potentials and transient outward current in myocytes isolated from rabbit left ventricle. J Physiol (Lond) 442: 191-209

25. Xu Z, Rozanski GJ (1998) $\mathrm{K}^{+}$current inhibition by amphiphilic fatty acid metabolites in rat ventricular myocytes. Am J Physiol 275:C1660-C1667

26. Tseng GN (1999) Molecular structure of cardiac $I_{\text {to }}$ channels: Kv4.2, Kv4.3, and other possibilities? Cardiovasc Res 41: $16-18$

27. Yeola SW, Snyders DJ (1997) Electrophysiological and pharmacological correspondence between Kv4.2 current and rat cardiac transient outward current. Cardiovasc Res 33: $540-547$

28. Franqueza L, Valenzuela C, Eck J, Tamkum MM, Tamargo J, Snyders DJ (1999) Functional expression of an inactivating potassium channel ( Kv4.3) in a mammalian cell line. Cardiovasc Res 41: 212-219 